DOI: 10.30842/ielcp230690152504

G. Blažienè

(Institute of the Lithuanian Language, Vilnius, Lithuania)

\title{
BALTIC ONYMS IN TIME AND SPACE
}

\author{
Г. Блажене \\ (Институт литовского языка, Вилнюс, Литва)
}

\section{Балтийские онимы во времени и пространстве}

Зарождение балтийских онимов во времени и пространстве приходится на II век, когда Птолемей (Geogr. 3,5,9) поместил на территории Aestiorum gentes Тацита два балтийских или прусских

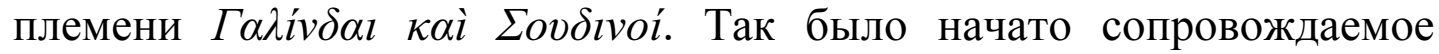
догадками, обсуждениями, гипотезами и подтвержденное неоспоримыми фактами великое движение галиндов не только на территории балтов, но и в Европе. Было высказано мнение, что имя галиндов упоминается в III в. на монете римского императора Волузиана. Об этом дискутировали выдающиеся нумизматы прошлого, а также на эту тему высказывались языковеды и специалисты по истории балтов. В статье подчеркивается, что ономасты фактически не могут исследовать и публиковать новые материалы без учета исследований историков и археологов, а также глубокого изучения исторических источников, подкрепленного современным более обширным пониманием вопроса. Это также относится к историкам и археологам, из поля зрения которых часто ускользают выводы исследователей лексики.

Исследования этнонима и хоронима «галиндский» междисциплинарны. Название Terra упоминается в латыноязычных источниках, т.е. в документах Тевтонского ордена и хрониках - 1231 Terre Pruzie.... Galindo (MHW I 1), 1254 Terram nomine Galando (CDP I 93f.), 1255 ...super terris Polexia et Golenz... (CDP I 98f.), 1267 Nom. Terra ...Galendia (MHW I 30). В XIV в. это имя фигурирует в знаменитой «Хронике земли Прусской» 1326 Terra Prussie in xl partes dividitur. ...Decima Galindia, in qua Galindite. (SRP I 51). В редко упоминаемой, но весьма важной для исследователей балтийского словника Хронике Иоганна Пластвига 1464 г. детально обозначены границы Галиндии. Упоминаются названия Terra Galindie, terra Galindiae (MHW III 30, 73-74) В наше время археолог Эугениюс Йовайша (2014: 55 ff.) начал воссоздавать миграцию галиндов, ее восточное и западное направления. В восточном направлении наименование галиндов зафиксировано в Ипатьевской летописи под 1147 г. в форме Гольдь.

В западном направлении много дискуссий вызвало частотное упоминание имен собственных с основой Galind-. При обращении взгляда на запад и восток были забыты происходящие с прусских земель онимы с Galind-, которые трактовались как производные с 
редким для балтийского словника суффиксом *-ind- (?) от лит. galas 'конец; окончание; смерть' или galia 'сила; мощь' и т.д. На прусских территориях выявлены ойконимы с *galind- и, по мнению автора статьи, они этнонимического происхождения, поскольку нельзя забывать о племенах и исторической памяти народов. В итоге ономасты опираются на первую запись ойконима, который в устной среде использовался иначе и гораздо более долгое время. По мере сил автором были уточнены онимы с galind-. Заслуживает внимания тот факт, что в Самбии [1331] был лес Galynde, Galinde, Galind; озеро Galinczeschobe в районе Ортельсбург возле Щитно (ок. 1420 г.); топонимы Gallinden, позднее нем. Gallingen, польск. Galiny в Ольштынском воеводстве (1336 г.); Galindien, позднее нем. Gallinden, польск. Gtędy в Ольштынском воеводстве (1345 г.); Gallinden, позднее польск. Gtędy в Ольштынском воеводстве (1785 г.).

Следует также кратко упомянуть имена собственные с galind- и обсудить взволновавшую балтийский мир находку испанского археолога Ксаверио Баллестера, а именно монету, на которой читается имя собственное Eivina[s]. Исследователи дискутируют о его балтийском происхождении, но при этом не учитывают немецкого словника собственных имен.

В данном случае необходимы объединенные усилия не только балтистов, но также германистов и романистов. Целью всех проводимых автором исследований является показать необходимость в исследовании оригинальных документов и словника исчезнувших языков, поскольку прусский язык еще не одно столетие после его официально засвидетельствованного исчезновения продолжал существовать в своем словнике в окружении немецкого и польского языков. Словник позволяет реконструировать ранее существовавшие лексемы и значимые исторические факты о прусских племенах и их распространении. Этнонимы следует изучать с источниковедческой, лингвистической, ономастической и исторической точки зрения.

Ключевые слова: галинды, этноним, прусский или балтийский словник, эпиграфы, исторические взаимосвязи.

\section{G. Blažienè. Baltic Onyms in Time and Space}

The life of Baltic onyms in time and space started in the $2^{\text {nd }}$ century CE, when the famous Claudius Ptolemy (Geogr. 3, 5, 9) placed two Baltic

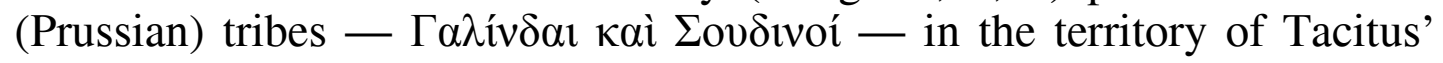
Aestiorum gentes. The great journey of the Galindians in both the Baltic lands and Europe began. This journey is full of considerations, assumptions, hypotheses, and real facts. It was believed that the name of the Galindians was also mentioned on the coin dedicated to Roman emperor Volusianus. The most prominent numismatists, linguists, and enthusiasts of the history of the Balts engaged in the discussion on this topic. The article notes that onomasticians cannot essentially investigate 
and publish new material without historians, archeological studies and continuous in-depth studies of historical sources and without referring to the available knowledge of a far wider scope. The same applies to historians and archeologists, who often eliminate the insights of the scholars of proper names from their focus of attention.

The research on Galind- as a name of region is a cross-disciplinary matter. The name of their terra is mentioned in Latin sources, i.e. the Teutonic Order's documents and chronicles: 1231 Terre Pruzie.... Galindo (MHW I 1), 1254 Terram nomine Galanda (CDP I 93f.), 1255 ...super terris Polexia et Golenz... (CDP I 98f.), 1267 Nom. Terra ...Galendia (MHW I 30). The famous $14^{\text {th }}$ century chronicle by Peter of Duisburg mentioned 1326 Terra Prussie in xt partes dividitur. ...Decima Galindia, in qua Galindite. (SRP I 51). The 1464 chronicle of Johann Plastwich, which is rarely mentioned but is nevertheless important for the scholars of Baltic proper names, gives a detailed description of the borders of Galindia. It says Terra Galindie, terra Galindiae (MHW III 30, 73-74). In our times archeologist Eugenijus Jovaiša (2014: 55 ff.) undertook the reconstruction of the Galindian migration and its waves to the east and to the west. The eastern-wave Galindians were mentioned in the Hypatian Chronicle: 1147 ГолАдь.

As regards their western wave, the frequent mentions of the personal names including Galind- are a matter of great controversy. While looking at the west and the east, the onyms with Galind-found in Prussian lands, which were usually explained as the derivatives of the very rare suffix *ind- (?) from Lith. galas 'end; demise; death' or galia 'power; strength', etc., were forgotten. There are oikonyms with *galind- in the Prussian lands, and the author of the article is convinced that they are of ethnonymic origin, because the historical memory of tribes and nations cannot be forgotten. Finally, onomasticians refer to the first record of the oikonym, which had been used in the spoken language in a different way and for a much longer period of time. The author substantially revised and updated (wherever possible) the interpretation of the onyms with galind-. It should be noted that the forest named Galynde, Galinde, Galind was located in Sambia [1331]; Lake Galinczeschobe could be found in Ortelsburg district near Szczytno circa 1420; Gallinden [1336], later Ger. Gallingen, Pol. Galiny was situated in Olsztyn voivodeship; also Galindien [1345], later Ger. Gallinden, Pol. Gtędy in Olsztyn voivodeship; Gallinden [1785], later Pol. Gtędy in Olsztyn voivodeship.

Also, the author found it necessary to briefly mention the personal names with galind- and to discuss the coin discovered by Spanish archeologist Xaverio Ballester, which aroused excitement in the world of Balticists, as the personal name Eivina[s] can be read on it. Scholars discuss its Baltic origin without drawing the material of German proper names. Balticists, Germanists and Romanists should gather forces to solve this riddle. 
The goal of the author's long-year research is to show the necessity of the studies of original documents and the careful investigation of the proper names of extinct languages, because the Prussian language existed, in its proper names, surrounded by German and Polish languages, for several more centuries after it was officially declared extinct. Proper names enable us to reconstruct former lexemes and important historical facts about former Prussian tribes and their geographical distribution. Ethnonyms should be discussed from the perspective of source studies, linguistics, onomastics, and history.

Keywords: Galindians, ethnonym, Prussian and Baltic proper names, epigraphs, historical links.

Memory has no end. Only the beginning. Everyone who endeavours to study the life and fate of the Baltic tribes, nations and languages is forced to start from the first mentions of the Baltic tribes or nations. Ethnonyms and onyms are the oldest witnesses of the Baltic languages. On the one hand, we can discuss Baltic onyms in time and space (we can find more sources starting from the $13^{\text {th }}$ century). On the other hand, it seems that the questions are so familiar to us that we start believing that there already are some undisputable answers. However, once we address the problems related to Baltic onyms in time and space with greater scrutiny, it turns out that every generation of researchers takes a different look at them and interprets the available data in its own peculiar way as well as tries to find the sources bringing us back to the solution of the intricate history of the Baltic legacy over and over again. The article will again consider the onym Galindians and related onyms by stating the well-known fact that the life of Baltic onyms in time and space started in the $2^{\text {nd }}$ century CE, when the famous Claudius

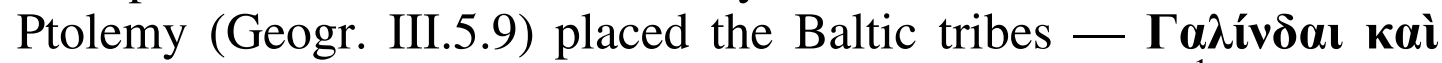

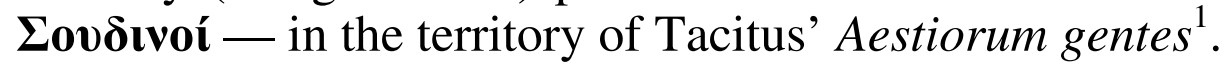

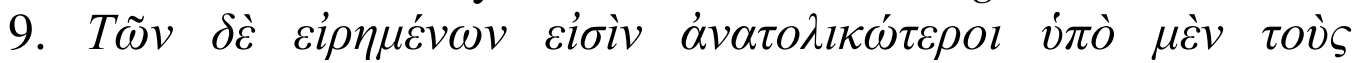

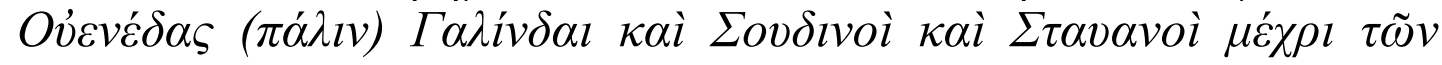

${ }^{1}$ Ergo iam dextro Suebici maris litore Aestiorum gentes adluuntur, quibus ritus habitusque Sueborum, lingua Britannicae propior (Tacitus, P. K. Germania, ca. 98 CE - see Alekna 2010: 3-4). Upon the right of the Suevian Sea the Aestyan nations reside, who use the same customs and attire with the Suevians; their language more resembles that of Britain. Translated by Thomas Gordon 2006 (http://www.gutenberg.org/ files/2995/2995-h/2995-h.htm The Project Gutenberg Ebook Of Tacitus on Germany, by Tacitus). 


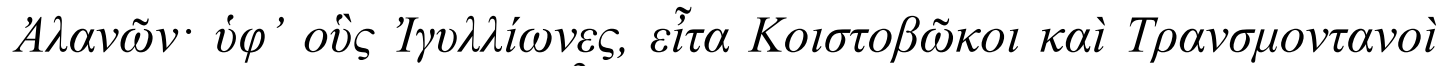

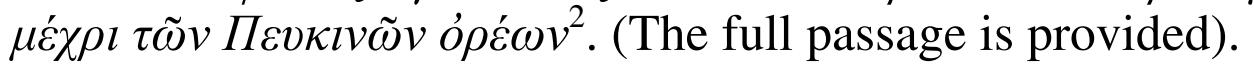

Among those we have named to the east: below the Venedae are the Galindae, the Sudini, and the Stavani, extending as far as the Alauni; below these are the Igylliones ${ }^{3}$, then the Coestoboci and the Transmontani [a Latin word in Greek characters] extending as far as the Peuca mountains.

Most likely Claudius Ptolemy (c. $100 \mathrm{CE}-$ c. $170 \mathrm{CE})^{4}$ received factological material from the informants - amber merchants - who mainly gathered in Dacia, a province of the Roman Empire which is located on the present-day Czech-Polish border, where the concentrations of the ethnonym Galind- can be found (see Jovaiša 2014: 144, etc.; 2020: 189-212). Nearly 1170 years later the Baltic Galindians and the Sudovians were mentioned in another work very important for the Baltic studies, which was written by Peter of Duisburg (d. c. 1326) in 1326. He was a German chronicler who was born at Duisburg and became a priest-brother of the Teutonic Order. He wrote the Chronicon terrae Prussiae dedicated to the grand-master, Werner of Orseln, who was one of the chief authorities in the history of the Order in Prussia (Encyclopædia Britannica 1911, Volume 21: 294). In 1853, Peter of

${ }^{2}$ Passage from Müller [1883]: 425-426.

${ }^{3}$ By the way, the Igylliones (called Igliones without $-\mathrm{y}-$ ) are mentioned in line 72 of the poem Radivilias. It shows that Ioannes Radvanus, a $16^{\text {th }}$ century Renaissance poet and protestant reformer from the Grand Duchy of Lithuania (died after 1592), read Ptolemy's Geography in search of Lithuanian ancestors: "Here the Duna flows as a stream in its upper reaches,/ it hurries to the land of Polotsk in rapid whirls,/ until finally it widely bursts into the Venedic Sea./ Not much smaller is the Lithuanian clearest river,/ the Vilia, which flows where the Igliones/ once had their lands and fertile fields: after taking its sister, the Vilna,/the Vilia runs down into the arms of its brother, the Chronos/no other river is more beautiful than the Chronos!... (see http://www.xn--altiniai-4wb.info/files/literatura/ LD00/Jonas_Radvanas._Radviliada.LD2700.pdf)_(lines 68-75). Translated from Latin into Lithuanian by Sigitas Narbutas (see Narbutas 1997). Yet another important mention of the Igylliones tribe was found next to BalticSlavic tribes (see Schönfeld 1911: 294).

${ }^{4}$ Ptolemy's years of birth and death are indicated differently, cf. Dini 2019: 63. The author referred to the data provided by Alexander Raymond Jones on January 20, 2012, which were published in the encyclopaedia, see Britannica https://www.britannica.com/biography/Ptolemy/Geographer 
Duisburg was mentioned by Max Töppen (Töppen 1853: 1-15), who later also prepared his chronicle for publishing (SRP I 21-219).

Ptolemy did not know (or perhaps he indeed foresaw) what immense interest, occasional confusion and persistent discussions his ground-breaking work, republished over and over again and yielding different interpretations, would arouse 2000 years later.

What is more, we should not forget the history of the coin which caused great excitement in the world of numismatists and linguists alike. This story deserves a special mention. If the assumption put forward by some researchers claiming that the coin includes the abbreviation of the ethnonym Galindians proved to be true, it would mean their very early mention. It was believed that the coins that included the title of Roman Emperor Volusianus, GAIUS VIBIUS VOLUSIANUS, who reigned during the crisis of the middle of the $3^{\text {rd }}$ century together with his father Trebonianus, CAESAR GAIVS VIBIVS TREBONIANVS GALLVS AVGVSTVS (251-253), also contained the name of the Galindians. The interpretation of the abbreviations inscribed in the coin caused and still cause great interest. Jean Foy Vaillant (1696: 351) deciphered the inscriptions in the following way (as Latin names): "Vandalos, Finnos, Galindas \& Vendenos memorat hoc tractu Ptolamæus lib. 3." It should mean: "Ptolemy places Vandals, Finns, Galindians and Venedi to this stretch in Book 3".

Joseph Hilarius Eckhel (1797: 369), the father of numismatics, discussed the views of other authors and provided his own reasoning:

Actually, the coins are inscribed with abbreviations. The notes on various coins are:

IMP. C. V. AF. GAL. VEND. VOLVSIANO AVG. AYTOK. К. Г. AФIN. ГA $\Lambda$. OYEN $\triangle$. OYO $\Lambda$ OY $\Sigma \Sigma I A N O \Sigma \Sigma E B$. А. К. Г. АФ. ГА . В. ВО $А O Y \Sigma I A N O \Sigma E Y \Sigma$. ГА. ВI. АФ. ГА.. .5

Eduards Volters, a prominent Latvian-born Lithuanian scientist and author of a number of works that have not lost their relevance to this day, published a conclusion in the Lithuanian press which

\footnotetext{
${ }^{5}$ Later, inscriptions on marble were discovered, as published by Ludovicus Antonius Muratori (1900: 321). These inscriptions indicate that the abbreviations are not names of the defeated tribes, but family names. Volusian is called in those records Vibio Gallo Veldumniano C $\Lambda$ io. Eng. "To Vibio Gallo Veldumniano", whereas the final word seems the distorted “CAES.”, i. e. "to Caesar".
} 
caused great disappointment among Baltic patriots and scholars willing to trace the ethnonym Galindians to the middle of the $3^{\text {rd }}$ century and even to the context of Roman emperors (1930: 342). Drawing upon numismatic works, he declared that the abbreviations inscribed in the coin meant the emperor's family names and strictly concluded that "this coin does not concern Lithuania".

The coin in question was also of interest to Slavicists. The prominent slavicist, Pavel Josef Šafařík, who published Slovanské starožitnosti [Slavonic Antiquities] (1837-1865) in Prague, gave his commentary on the coin and presented his own interpretation of the

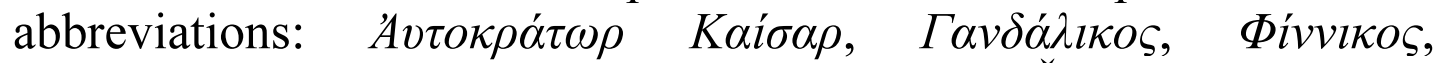

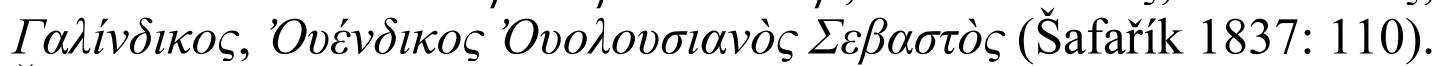
Šafaŕík understands it as follows: "Caesar, Galindian, Finnish, Galindian, Venedian Volusianus Augustus". It should be written as

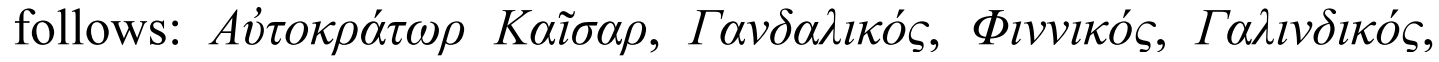

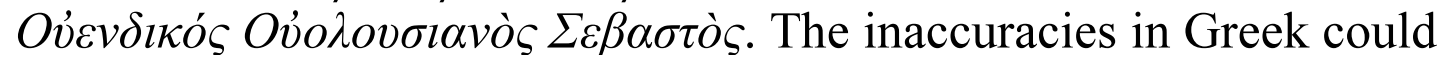
either be explained by printing errors or limited knowledge of the Greek language. It is difficult to explain the form Gandalikos as a spelling error alone. The Latin spelling is correct: Imperatori Caesari Vandalico, Finnico, Galindico, Venedico, Volusiano Augusto. It would mean: "To Emperor Caesar, Vandalian (sic), Finnish, Galindian, Venedian Volusianus Augustus".

There were various attempts of explanation. Vladimir Nikolayevich Toporov is also worth mentioning. He has no doubt that the ethnonym Galind- was indeed mentioned in the coins that include the title of Roman Emperor Volusianus and mention Galindians as

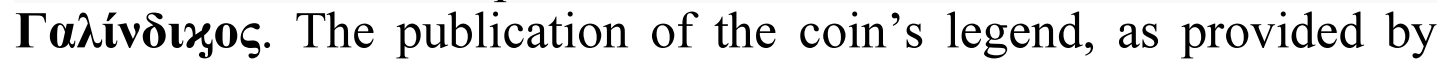
Vladimir Toporov (1980: 125; also see Toporov 1980a: 248), contains some errors. Toporov published the inscription as follows:

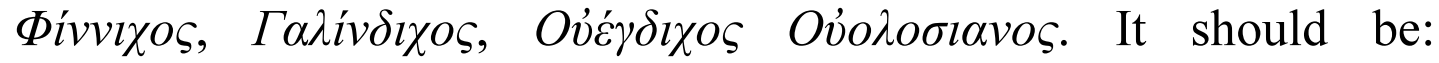

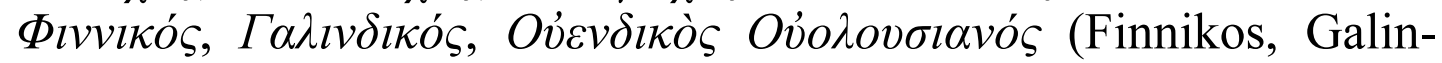
dikos, Vendikos, Volusianos).

It is likely that Toporov actually followed Šafařík's reasoning. It should be pointed out that in Volume 2 of his famous work The Prussian Language. Dictionary Toporov (1979: 138-142) named the Prussian land Galindo referring to the sources of the $13^{\text {th }}$ century which will be discussed hereafter. The abbreviations on various coins are as follows: 

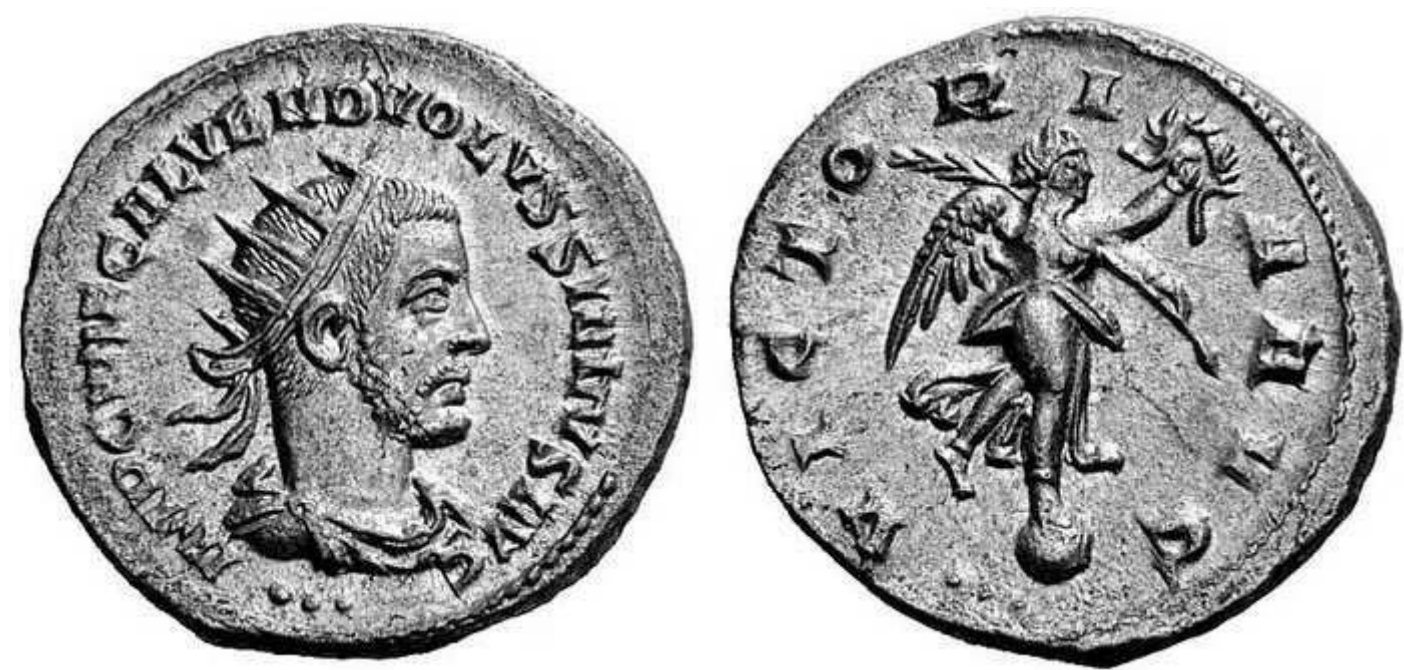

Other decipherings: Caio Vibio AFinio GALallo VENDumniano

IM C AF GAL VEND VOLVSIANO AVG.

IM C AF GAL VEND VOLVSINO AVG.

IM C V AF GAL VEND VOLVSIANO AVG

IMP C AF GAL VEND VOLVSSIANUS IV

IMP C V AF GAL VEND VOLVSIANVS AVG

IMP C V AF GAL VEND VOLVSIANO AVG

IMP C V AF GAL VEND VOLVSIANVS AVG

IMP C V AF GAL VEND VOLVSSIANVS AVG

IMP C V AF G M (VEND) VOLVSIANO AVG

(See https://www.jassa.org/?p=1915)

When such hypotheses arise, it is again becoming important for present-day scholars to gain a deeper insight into this coin. ${ }^{6}$ All the available written sources were reviewed in order to justify or reject the link between the coin and the Galindians. Whereas new coins of interest to the researchers of Baltic proper names are still discovered from time to time, perhaps it will not take a century before we get the answers to most of the questions. Not only the technologies

\footnotetext{
${ }^{6}$ Referring to disputable material, the enthusiasts of the history of the Balts again try to prove that the Balts were mentioned very early and they were spread all over Europe. Independent researcher Oleg Dmitrievich Fedchenko (2020: 104-127) argues that there are far more hydronyms of Baltic origin in Central Russia than provided by Toporov, Trubachev, and Otkupchikov, e.g. Luža, Pjana, Súchona, Tambov Lesnoj and other oldest toponyms in the Russian Federation are of Lithuanian origin. Amateur researchers promptly concluded that the oldest toponyms of the Russian Federation are of Lithuanian origin.
} 
helping to read the inscriptions carved in coins, stones, bark, etc. will develop but new written and printed sources still hidden in archives will be discovered. By the way, one coin of Trebonianus Gallus was found in Lithuanian burial grounds; two coins of Volusianus were found in Pomerania and one coin was discovered in Masuria (Jovaiša 2014: 100).

The great journey of the Galindians in both the Baltic lands and Europe began. This journey is full of considerations, assumptions, hypotheses, and real facts. The question may (and does) arise, and we still need to prove or deny whether the return to the question of Galind- is required. Archeologists, namely Eugenijus Jovaiša (2014: 89, etc.) (also see Wojciech Nowakowski (1995; 1996: 329330), who places the Galindians in Masuria when speaking about the Bogaczewo culture, good connections with amber and amber trade route, which is called the Amber Road by Jovaiša), say a very important thing: there are grounds to believe that the Galindians, together with the Balts of the Wielbark culture and Sambian Aesti, did not only control the origins of the Amber Road but also the end of the "barbarian" Amber Road near Roman Dacia. It should not be forgotten that onomasticians cannot essentially investigate and publish new material without the research of historians, archeologists and continuous in-depth studies of historical sources and without referring to the current knowledge of a far wider scope.Therefore, the research of Galind- as a name of people and region is a cross-disciplinary matter. The name terra is mentioned in Latin sources, i.e. Teutonic Order's documents, chronicles. The mentions of the land of Galindia in written sources are presented below. The name Galindo first appears in 1231.

1231 werden auf Befehl des dänischen Königes dessen südbaltische Besitzungen in Preußen in folgender Weise ins Rechtslagerbuch eingetragen: Terre Pruzie ex una parte [fluvii] Lipz Pomezania, Lanlandia, Ermelandia, Notangia, Barcia Peregodia, Nadravia, Galindo, Syllones, Zudua, Littovia: ex altera parte Lipz Zambia Scalwo, Lammata, Curlandia, Semigalia (erstes urkundliches Auftreten des Namens Ermeland). Eng. "By the order of the Danish king, his southern Baltic domains were registered in such sequence. The name of Warmia was for the first time mentioned as Ermeland" (MHW I 1).

1254 ... terram que maior Bartha vulgariter appellatur Warmiensis dioceses ac terram nomine Galanda prope pontum. (Papst Innocenz IV. fordert die Bischöfe von Kulm, Pomesanien und Ermland auf, den Orden in Preussen auf alle Weise zu unterstützen 
und ihn in der Erhaltung des zum Christenthum neubekehrten Länder Groß Barthen und Galindien zu schützen). Eng. "Pope Innocent IV urges the bishops of Kulm, Pomesania and Warmia to support the Order in Prussia in every way and to protect it in the preservation of the countries newly converted to Christianity, Great Bartha and Galindia)" (CDP I 93f.; cf. Voigt 1828: 57).

1255 ....super ter Leris Polexia et Golenz... super terris Polexia et Golenz... (CDP I 98f.) (Pope Innocent IV gave the lands of Polexien and Galindien to Casimir, Duke of Kuyavia (Voigt 1828: 96).

1267 Nom. Terra Culmensis, Lubouia, Soysim, Pomizania, Pazluch, Landesen, Sambia, Pogzania, Warmia, Natangia et Bartha, - Galendia, Getwesia et Lutouia. (September 1267, Prague. Czech King Ottokar concluded a treaty regarding the subjugation of Galendia, Getwesia et Lutouia (Ger. König Ottokar von Böhmen schließt mit dem D. Orden einen Vertrag wegen Unterwerfung Galindiens, Jaczwingiens und Lithauens. Acta sunt Prag A. domini mcclxvii cf. Dipl. Nr. 51.) (MHW I 30). (It is important to note that scholars have just recently begun the reconstruction of the Galindian migration and its eastern and western waves (see Jovaiša 2014: from p. 55). Hence, the mention of the eastern-wave Galindians Голядь — in the Hypatian Codex (PSRL II 1147: 29) is noteworthy. As regards their western wave, the frequent mentions of personal names including Galind- are a matter of great controversy. It should be added that bearing in mind the great diversity of studies and insights of both linguists and archaeologists, the eastern-wave Galindians should again fall into the scope of attention.

Perhaps the above documents of the $13^{\text {th }}$ century are neither exhaustive nor absolutely reliable, but their significance should not be doubted. 59 years after the document just mentioned above, in 1326, the chronicle by Peter of Duisburg, which is perfectly known to scholars, came to life. The Chronicle of the Prussian Land was written in 1326 but it gives account of earlier events. Namely, all onyms date to 1326 but the events happened long before. The author writes about the castle in Torun built in 1231 (SRP I 49). It is doubtful whether the division of Prussians should be dated to 1326 . The studies of all the sources used in the chronicle as well as the precise dates of events and facts could constitute an object of a separate study. ${ }^{7}$ Most likely, the author wrote his chronicle in the

\footnotetext{
${ }^{7}$ The chronicle was published in Lithuanian in 1985. Of course, the translation would have been much better if the original text accompanied
} 
Königsberg Castle and described the history of the German Order in Prussia until 1326. The division of Prussians was presented at the beginning of the third book: EXPLICIT SECUNDA PARS LIBRI INCIPIT TERCIA PARS DE BELLIS FRATRUM DOMUS THEUTONICE CONTRA PRUTHENOS (Eng. "END OF THE SECOND PART OF THE BOOK, BEGINNING OF THE THIRD PART. ABOUT THE BATTLES OF THE BROTHERS FROM THE HOUSE OF THE TEUTONIC ORDER AGAINST PRUSSIANS"). It speaks about the division and might of Prussians and enumerates 11 parts: Terra Prussie in xl partes dividitur. Prima fuit Colmensis et Lobovia, que ante introitum fratrum domus Theotonice quasi fuerat desolata. Secunda Pomesania, in qua Pomesani. Tercia Pogesania, in qua Pogesani. Quarta Warmia, in qua Warmienses. Quinta Natangia, in qua Nattangi. Sexta Sambia, in qua Sambite. Septima Nadrowia, in qua Nadrowite. Octava Scalowia, in qua Scalowite. Nona Sudowia, in qua [habitabant] Sudowite. Decima Galindia, in qua [habitabant Galindite]. (Galindia, which was inhabited by the Galindians). Undecima Bartha et Plicka Bartha, que nunc major et minor Bartha dicitur, in qua Barthi et Barthenses habitabant (SRP I 51-51).

The researchers of proper names should remember the above date, because the oikonyms provided below were recorded at around the same time. We may discuss what an onomastician has to pick out from the documents - a bare onym or an onym accompanied with a context. If the researchers of Prussian proper names who had a rather easy access to the documents of the Teutonic Order had provided the context and picked out all the possible variants of a single onym, we would now be armed with the powerful material not only for the research of onyms themselves but also of the settlements that they named and of the region under investigation, its history, language contacts, and, most importantly, we would now have particularly reliable data enabling us to determine the origin of onyms.

1335-1341 Teilungshandfeste (Privilege of Division) Dys synt die teylungen der lande tzu galynden tzwisschen Angerburg und Letzemburg, die meister Dittrich hat gemachet im lande zu Galinden... (Eng. "These are the divisions of lands in Galindia

by Toeppen's comments had also been provided. Another loss for science is the "translation" of proper names into Lithuanian. It is doubtful whether any young-generation historians will take such a deep interest in the contents of the text to start reading it in Latin. 
between Angerburg ${ }^{8}$ and Letzemburg ${ }^{9}$ made under the order of Dietrich, the Grand Master of the Order, in the land of Galindia" (Toeppen 1870: 64-65; see Kasiske 1934: $103^{10}$ )). Prussian onyms are also mentioned in the document, but, according to Toeppen, they were written particularly inaccurately.

The scholars studying Baltic proper names failed to notice the chronicle written in 1463-1464 by the dean (Domdechant) of Warmia, Johannes Plastvici (Plastwich), which abounds in Prussian proper names collected from the spoken language and well localizable. Having subjugated the Prussian lands in the $13^{\text {th }}$ century, the Teutonic Order shared them with the Diocese Capitulum. The author of the chronicle also mentioned the events of 1463. Plastwich's chronicle is based on a shorter variant, the so called Denkschrift in German. It is a letter about certain important matter, an abbreviated version intended for official persons or services (MHW III 41-137).

1464 Terra Galindie, terra Galindiae... Et est notandum, quod terra Galindiae fuit a Bertingen usque ad Poloniam, et Gunlauken usque ad Poloniam, et a Barten usque ad fluvium Nare et usque ad Sudoviam, ita quod tota terra intra Nadroviam et Sudoviam et Poloniam usque Bertingen, Gunlauken et Barten fuit terra Galindia. (Eng. "It should be noted that the land of Galindia stretched from Bertingen and from Gunlauken up to Poland and from Barten to the Nare River and Sudovia, so the entire land in Nadruvia and Sudovia and in Poland up to Bertingen, Gunlauken and Barten was the land of Galindia" (MHW III 30, 73-74)). The map presented below was created from the well-known $14^{\text {th }}$ century map of the Prussian lands and overlaid on the Galindian territory according to the coordinates given by Plastwich. The map features the inscriptions from the chronicle: the great Galindian king lived near a big lake called Nabentine, which was half a mile away from the Leiczen part towards Lithuanians and the king's name was

\footnotetext{
${ }^{8}$ Now Weggorzewo, a town in northeastern Poland, the Warmian-Masurian Voivodeship.

9 Now Giżycko, Ger. Lötzen, a town in the Warmian-Masurian Voivodeship.

${ }^{10}$ Karl Kasiske provides an excerpt from a complex document read by Toeppen as follows: Dys fynt die teylungen der lande tzu galynden tzwifchen Angerburg und Lelzenburg, die meifter Dittrich hat gemachet (Eng. "These are the divisions of the land of Galindia between Angerburg and Lötzen made by Master Dittrich"), in which Galinden is not mentioned for the second time.
} 
Ysegups (MHW III 74). And when the same master asked them about the borders with Mazovia, they answered, 'We don't know them...' (MHW III 75). After a scrupulous study of the said chronicle, it was a pity to realise that while analysing Prussian ethnonyms and onyms, the author and other scholars of Prussian proper names disregarded some very interesting and rich onyms of that land. Unfortunately, this material is not reflected in the highly valuable multivolume dictionary Nazwy miejscowe Polski (Polish Place Names), compiled by Polish onomasticians, whose first volume was published in 1996.

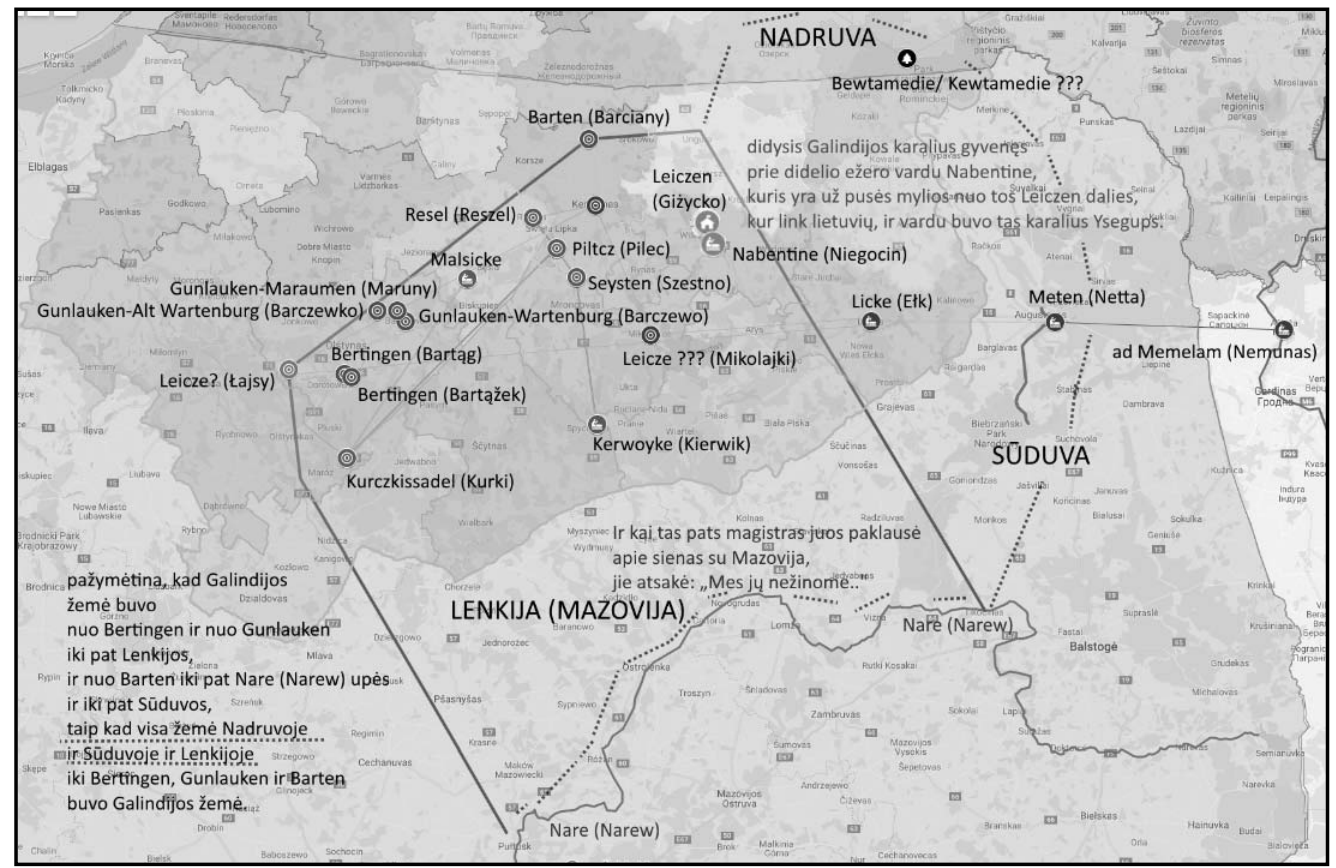

$14^{\text {th }}$ c. map of the Prussian lands overlaid on the Galindian territory according to the coordinates given by Plastwich. Based on the author's translation of the chronicle from Latin, the map was created by Edmundas Trumpa.

If we look at the west and the east, the onyms with Galindfound in Prussian lands appear to be forgotten. These were usually interpreted as derivatives, with the suffix *-ind- (?), from Lith. gãlas 'end; demise; death' or galià 'power; strength' (LKZe), which were almost unrecorded in the Baltic proper names. At this point, we should also mention the attempts to explain the etymology of Galindia. Vytautas Mažiulis (2013: 207-208) ${ }^{11}$ believes that the name should be linked with the long-extinct river name $*$ Galinda see Toporov (1979: 141-142), Pietro U. Dini (2014: 308-310). Still, we should agree with Schmid (1996: 326) that in explaining

\footnotetext{
${ }^{11}$ The article refers to the revised and expanded second edition of the fourvolume Etymological Dictionary of Prussian by Vytautas Mažiulis.
} 
etymology, we should first take into account what was mentioned first: the name of the people or the name of the country. In the case of Galindia and the Galindians, we should remember by referring to Ptolemy that the name of the people was closer to the Greek geographer and we can thus think about galingas, galinčius 'mighty, strong man' (LKZe). In the opinion of Simas Karaliūnas (2015:72), the etymology should be sought by also referring to the formally coinciding Gr. $\chi 0 \lambda \alpha ́ \delta \varepsilon \varsigma$ 'insides, intestines' as well as the equivalents in other languages. For instance, in addition to other meanings, Lith. skilándis can also mean 'stomach' (LKZe).

There are toponyms with * galind- in the Prussian lands, and there is almost no doubt that they are of ethnonymic origin, from galindas (also see Schmid 1996: 325-326). When people abandon or are forced to abandon their native lands, they take their biggest property - language and names - with them, which is undoubtedly used in the nomination of various objects, usually settlements, but there are also other objects of ethnonymic origin. The article will further focus on the onyms with galind- after their interpretation has been substantially revised and updated (wherever possible).

There was a forest in Sambia: [1331] ... circa silvam Galynde (Galinde, Galindin) dividunt hos cameratus Girmow et Rynow (... near the Galynde (Galinde, Galindin) forest it divides these commanderies of Girmow (Ger. Germau, now Russkoje) and Rynow (Ger. Rinau, now Tschaikino). Deinde ad aliam quercum circumfossam stantem in fine eius silve Galind et villam (!) circumfossam, que dicitur esse granicia illorum de Kaldeyn (Kalideyn, Kaldeynen) (Ger. Kallen, now Cvetnoje) (SUB 118). (Then near another trenched oak standing at the end of the Galind forest and near the trenched farmstead (!) ${ }^{12}$, which is said to be the border of those from Kaldeyn). According to the document, the forest was quite large. It was situated in East Sambia near the Baltic Sea. Undoubtedly, the forest could be named by the newcomers who called themselves Galindians from former Galindia. The historical memory of tribes or nations should not be disregarded.

Around 1420: Galinczeschobe lake, (Ortelsburg district) near Szczytno. Non-identifiable (Gerullis 1922: 35; Biolik 1993: 35), Pr. *Galind-sōva, compound from Galinder and Pr. *sōva 'lake' (Schmid [1985, 1986]: HE, Einführung 7). Prussians who referred to themselves as Galindians also named the lake after them. Still, we

\footnotetext{
${ }^{12}$ It would also be important to identify the name of the farmstead, which may be related to the name of the forest.
} 
should be more prudent and perhaps suggest a bold thought as to whether the second component of the compound is not related to their dialect. Pr. *sōva is a reconstruct, and without the data at hand, it is difficult to even think about the dialect spoken in those areas. The name of the lake could also be found in the regions of galind-. The use of $c z$ instead of $d$ can probably be explained by the influence of Polish.

The goal of the author's current research is also to show that studying original documents is indispensable for the most accurate possible research of an extinct language, namely Prussian, and of its proper names. Indeed, it is essential for a lost language and its proper names, from which we can reconstruct former lexemes and very important historical facts about the lands and the former ethnic composition of their inhabitants. The names of settlements which, in the author's opinion, are of ethnonymic origin and should be associated with the Galindians are discussed below. Abbreviated descriptions from the sources are provided.

Galiny is located in Olsztyn voivodeship, Bartoszyce district, 10 km south of Bartenstein, Ger. Gallingen ${ }^{13}$.

1336 (Transcript 1585) ...ville Gallinden nuncupate... Handfeste des Komturs von Balga über Gallingen (Privilege of the Balga Commander to the village called Gallingen). PUB III 59-60.

1374 ...vnde von dannen vort czu gehin zcu der Ortsgreniczen, die do scheidit Galindin vnde Trutenow... (From there travel to the border of the locality separating Galindin from Trutenow) CDP III 161.

1437/1438 Gallieden item 99 czinshubin... KA Bartenstein (there are also 99 hubin (land measurement unit) on which land tax is imposed in Gallieden... Bartenstein commandery) OF 131143.

1437/1438 Gallieden item 3 kreczemer...(there are also 3 inn-keepers in Gallieden) OF 131 145. Later Gallingen, Friedland county (GZB 154).

Circa 1550 Galinden MHW III 442, 440.

1570 Gallingenn HAPr. V 35.

1785 Gallingen noble manor and peasant village with a church and a watermill. 48 fireplaces Goldbeck I 50.

1796-1802 Gallingen Schrötter XI.

1881 Gallingen Evangelical church, from 1589, a manor with a park, 12 $\mathrm{km}$ of Bartenstein, a brickyard SGKP II 476.

1946 Gallingen — Galiny Leyding I 7.

1993 Galiny Przybytek 1993: 58.

${ }^{13}$ Not all orthographic variants found by the author are provided. Otherwise, the scope of the article would be much too wide. It is the aim of other articles. 
Considering the context provided in CDP, the localization does not raise any doubts. The author tends to associate $\operatorname{Pr} .{ }^{*}$ Galind- with the ethnonym galindas. The change of suffixes is a late phenomenon. At the end of the $16^{\text {th }}$ century the change of the suffix $-n d->-n g$ - is observed, which is explained by the influence of Low German (Gerullis 1922: 223). The suffix -ind is not identified in other Prussian onyms. There are a couple of surnames with this suffix among Lithuanian proper names Tiliñde, which possibly derive from Lith. tilindúoti 'to strike, knock; to fawn upon, flatter; to ring', tilindžiúoti 'to sound softly' (LPDB). The suffix is attributable to the base word. The surnames provided by Pranas Skardžius (1943/1996: 102) Dalindà, cf. Delinda, are not the best examples, because these surnames definitely derive from Bel. Даленда, Дзелендаў, Дзялендзік (LPDB), from which the suffix originated as well. Also compare Lithuanian personal names Galindas, Galinda, surnames Galindžus, Klebindžus (Kalwaitis (1910: 3, 5, 10, 12) collected examples from the spoken language, but Galindas, Galinda are the names of historical memory). Gerullis provides the examples of this change - 1345 Galindien: 1469 Gelyngenn, now Gallingen, but both oikonyms are orthographic variants of different oikonyms, because the author of this article managed to correct the recors of Gelyngenn, later Gallingen, given by Georg Gerullis (1922: 35) and other onomasticians. There is no change of suffixes $n d>n g$ in this case, because 1345 Galindien is another oikonym, whereas in the case of Gellyngen, the suffix -ing- already occurs from the first record.

Ględy Olsztyn voivodeship, Łukta district (gmina), $13 \mathrm{~km}$ southeast of Morag.

1345 (Transcript XV) Title Galindien about IV hoken (land measurement unit), obir IV hoken, Galynden (title), Galindien, Galinden PUB III 622 (see Wunder 1968: 105).

1348 wyr Bryder Hynrich Tusemer homeyster des ordins der brudere ... vorlyen und geben XXV huben in dem walde Smagars (Smagars $($ Smagury $)=$ Gut des Jongirman $=$ Tirwoten $=$ Gallinden $)$ gelegen unseren getruwen... ydirman mit syme bescheyden teyle besundern: Swayprote, Santap, Narune, Globune (V huben) und Noke (Noyke) und Bandule mytanandir $V$ huben von czenden und geburlichen erbeyt fry... PUB IV Nr. 337 298-299, cf. Hartmann 1958: 121.

1348 (Transcript XIV) privilegium von Gros Galinden (Privilege of the manor Große Gelynden) PUB III 298.

Circa 1400 Glalinden (incorrect spelling), should be Galinden (OF 161 131b-132a), Galynden, Galynden CA Neymen (OF 161 152), Galynden, Galinden (ibid. 164a). In Order's Folio 161, 
which is also called Das Pfennnigsschuldbuch der Komturei Christburg (Eng. "Christburg Commandery's Debt Book"), the toponym was recorded 15 times in the same district (gmina), now Niemoje. A high number of recordings of the same oikonym shows that Gerullis localized the toponym inaccurately by presenting it as a later orthographic variant of Gallingen in Górowo Iławeckie district, Olsztyn voivodeship. The locality was situated in Christburg (Dziergoń) commandery, Nehmen, later Pr. Markt district. It means that the inaccurate data about the oldest testimonies of the present Galiny provided by Rozalia Przybytek (1993: 58, also cf. 70) and NMP II 71 (who took the records or inaccurate localization provided by Gerullis for granted, without questioning them) require a thorough revision of all the orthographic variants recorded in the above works and the correction of their localization, because the oikonym in question was recorded in an absolutely different place of Prussia. The diligent publisher of OF 161, Heide Wunder (1969: 9), observed that the material of Prussian proper names is not exhaustively evaluated. It is regrettable that the authors of NMP did not use this highly reliable source. The Polonized toponym is an even more complicated matter. When Polonizing, the form with incorrect spelling, Glalinden, was used. Galinden was written by the same hand in smaller letters in OF 161 131b-132a, most likely for correction purposes (cf. Wunder 1968: 163).

There is considerable confusion concerning this recording in Przybytek (1993: 70-71) and NMP II 71 as it was unjustifiably included in the recordings of later Galiny (NMP II 71) in Olzstyn voivodeship, Górowo Iławeckie parish.

1437/38 Galinden hat 5 dinste. Cameratus Neymen (Galinden has 5 armed men) OF 1311361559 Der Galinder Willkür (Galindian arbitrariness) Hartmann 1958: 121-124 (but it is not the mention of an oikonym as believed by Przybytek but rather the indication of inhabitants). It is further specified:

1593 die Gallinder Hartmann 1958: $124^{14}$.

${ }^{14}$ A devoted connoisseur of the region and related sources, Ernst Hartmann (1958), wrote in his book dedicated to Osterode county (Pol. Ostróda, Ger. Osterode, Lith. Ostruda), a town in northern Poland near the Kaliningrad Region, that the residents of the village were called Galindians in the $16^{\text {th }}$ century and later. They were also referred to as Galindians in the $14^{\text {th }}$ century. As pointed out by the author (1958: 121), at the beginning of the $16^{\text {th }}$ century all Prussian families in the Galindian village died out. Hartmann states (ibid. 125) that in 1592 the descendants of former residents who were looking for a new home and better life or perhaps were 
1600 die Gallinder Hartmann 1958: 124.

1785 Gallinden Kulmish village with 20 fireplaces Goldbeck I 50.

1796-1802 Gallinden Schrötter XVI.

1820 Gallinden (Glendy) Prussian free village, 24 fireplaces, 131 inhabitants, Morag, Hartmann 1958:126.

1881 Gallinden, Ględy (Glendy) (1) village, Ostróda voivodeship SG II 476, 580.

1946 Gallinden - Ględy village Leyding I 74.

The village Gallinden located on the eastern shore of Lake Röthloff could owe its origin to a similar resettlement of Prussians from other regions. The name of the village points to the Galindians who were given land in the wilderness (Wunder 1968: 194). Wunder (ibd. 195, 213) writes: "the settlement of the Galindians in Gallinden"; "Prussian village Gallinden". 1538/39 Gallinden was home to the great free farmers (Ostpr. Fol. 911a 15, 216). Wunder mentioned the name more times.

From the ethnonym galindas derives the name of the inhabitant of Galindia (NMP III 143), hence, Pr. *Galind-. It was already Hartmann (1958: 120-121) who noted that the village name is most likely associated with the name terra Gallinden (Galinden).

In addition, the mention of the oikonym and very interesting data from the settlement's history are provided. Not only the mention of the name itself but also other non-onomastic-type data would be of great value to onomasticians, as they would be of help for localization purposes; after all, we speak about historical toponyms. Hartmann (1958: 123) gave a detailed account of the village, listed the fireplaces and inhabitants (there were 481 people in 1880) and described their cattle. In 1895, the village had 433 hectares of land, the population of 400 people, 192 men among them (extralinguistic information). He did not speak about their nationality. Perhaps there still were some descendants of Germanised Prussians who called themselves Galindians.

Ględy Olsztyn voivodeship, Maldyty district (gmina), $9 \mathrm{~km}$ south-west of Morag (NMP III 143).

1785 Gallinden noble manor and folwark, 2 fireplaces in the county of Morag near Jäskendorf Goldbeck I 50. 1796-1802 Gallinden Schrötter XVI.

led by historical memory purchased the empty village for 1200 marks. The village name remained unchanged, as it reminded of the history of their ancestors. The details of this type or the traces of the Galindians imprinted in the names in this case are sometimes disregarded by the researchers of proper names. 
1820 Galinden 6 fireplaces and 50 souls belong to Jäskendorf, Ostróda county, Wald 195.

1881 Gallinden (2), now Ględy (Glendy), folwark in Morąg voivodeship, Maldeuten district 1881 SG II 476, 580.

1946 Gallinden - Ględy folwark Leyding I 46.

In the opinion of the author, the name of the village Pr. * Galindis also of ethnonymic origin. We should not forget the fact that place names travelled in the historical memory of the people. As regards the distribution of the oikonyms with *galind-, we can state that there are some signs of areal onomastics.

We should bear in mind that the name was created by the scribes of the Teutonic Order. It was taken from the spoken language, from Prussian. There are no real data concerning the existence of the name, because only the first mention of the name, which could have been in circulation for several decades or even a century in historical documents, is known today.

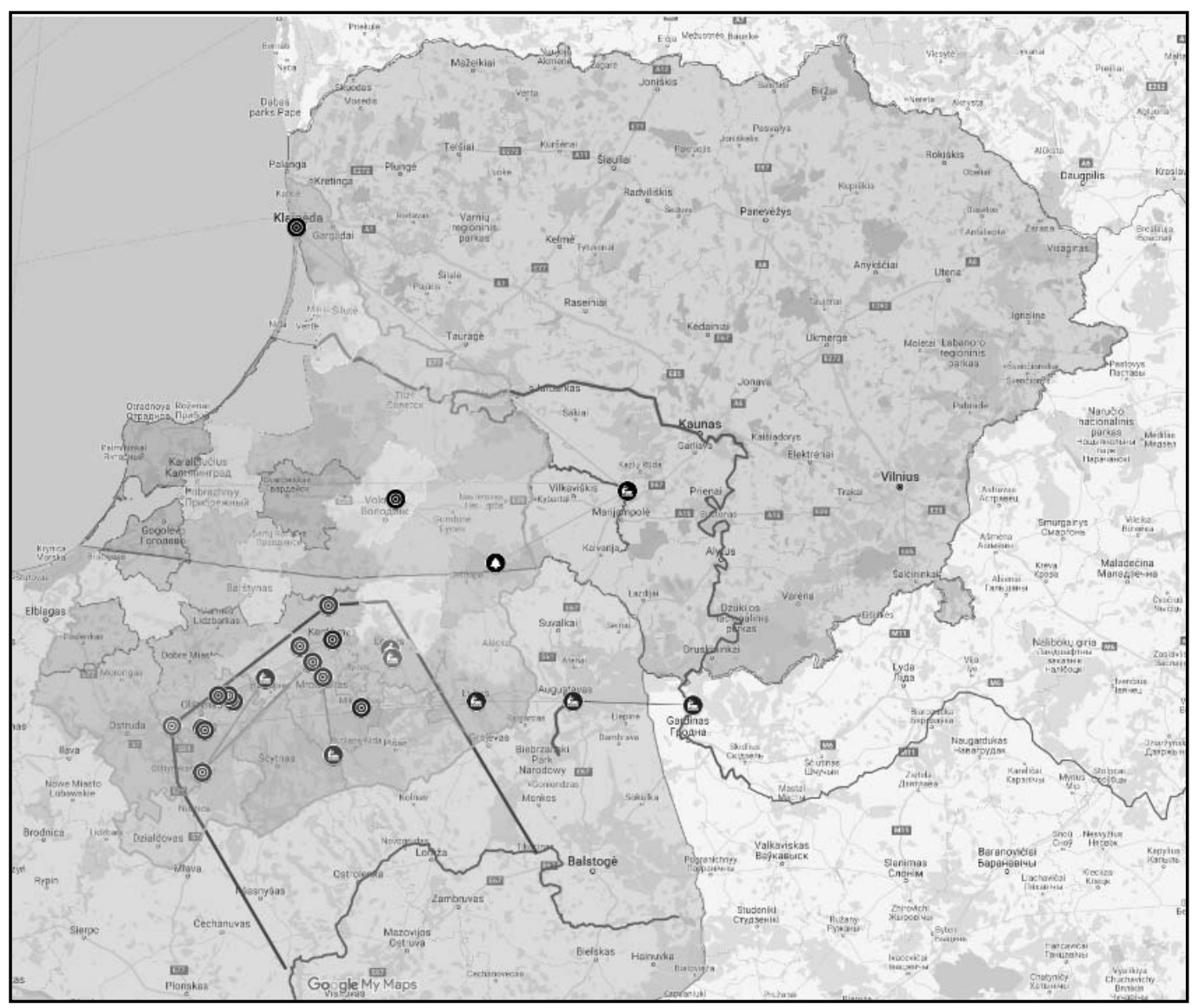

The map General Picture of Galindia

Idea author: Grasilda Blažienè, created by: Edmundas Trumpa.

Further, the personal names with galind- spread in Europe will be briefly mentioned. The topic of the personal names with galind- 
would require a separate article and thorough studies. A number of researchers formulated hypotheses concerning the participation of the Galindians in the processes of the Migration Period. Toporov (1983 (1982): 129-139) came up with a hypothesis about the Galindians in Western Europe by providing personal names with galind-. Following in the footsteps of the Goths, the Galindians travelled to the territories in Western Europe up to the Iberian Peninsula, which have already been mentioned by other scholars for a number of times. Some researchers reject Toporov's hypothesis without reservation (see Luchtanas, Poliakovas 2018: 9-39) stating that the migration of the Galindians is an obvious error. Such statements, which are not supported by thorough studies of written and printed sources, are not convincing. In order to reject the opinion of the scholar whose merits in the study of Baltic languages are undeniable, the documents referred to by all the cited authors should first be reviewed, because scholars tend to refer to known authors and do not bother to collect empirical material. If, according to the authors, the ethnonym of Galindia appeared in the $2^{\text {nd }}$ century $\mathrm{CE}$ and disappeared in the $13^{\text {th }}$ century (ibid. 34), it means that the authors are not familiar with Prussian onymy. As pointed out by Pietro U. Dini (2019: 252), Galindian personal names could be found "in the area of Castile, Catalonia and Portugal". We can and sometimes we have to revise the hypotheses raised by our predecessors, but then we also have to refer to the works of those scholars who are not convenient, as they provide a number of new facts. Unfortunately, this is not always the case.

In his famous book The Book of Old German Names (Ger. Altdeutsches namenbuch), Ernst Förstemann (1900: 591) gives several examples from Aragón and France by saying:

Also compare... Ptol. as well as the East Prussian land of Galinden: the personal name would then be a reminder of the Baltic homeland of the Goths, compare also Galindus, Galindo (Förstemann 1856: 466) and De Divisiaco quod habuit Galindus (from [the locality called] Divisiacum ruled by [the man called] Galindus. The locality is Divisiacum; it seems that it is the town Dizy in France near Reims.

Georg Sachs (1935: 52) stated that the Galindians followed the Goths on their wanderings. By the way, compare the book important for the researchers of personal names - Joseph M. Piel, Dieter Kremer (1976: 143-146) - which essentially repeats the assertion of Förstemann (1900) by saying that Sachs goes too far by his statement. Ernst Gammilscheg (1934: 315) writes about the Gothic 
*GALINDS 'Galinder' by adding that Galindus, Galind were mentioned in the Cart. Toulouse for 16 times.

Also, see Joseph M. Piel, who wrote in 1936:

The origin of the anthroponym is the Galindian people who belonged to the ethnic group of the Aestians (AESTII) referred to by Tacitus in Chapter 45 of Germania and who lived in the second century in the mouth of the Vistula River. They are Ptolemy's $\Gamma \alpha \lambda \iota v \delta \alpha 1$ and do not appear to be German but belong to the Baltic linguistic branch which the Old Prussians also belong to. The name was perpetuated from the region of Galindia in East Prussia. (Piel 1936: 12).

The study of literature revealed that Spanish scholars still write about the Galindians as a Baltic tribe. Francesc de Borja Moll (1982: 104), when discussing the situation of Catalonians, mentions Galî De Galindus, que coincideix amb el nom d'un poble bàltic (Eng. "Galî. From Galindus whose name coincides with the name of a Baltic tribe"). The works of Luis A. García Moreno 1997, 2008 and others are also worth mentioning. By the way, Toporov's critics do not mention their names and insights. Only well-grounded discussions are possible in the scholarship. It should be noted that in September 2019 the prominent German onomastician, Dieter Kremer, wrote to the author of this article that most likely the names deriving from the ethnic group of the Galindians are meant, because in addition to the Galindians, the Goths also mentioned others, e.g. Bulgars.

It would be useful to systemize and extend the problem to the position of the German studies by also not forgetting the so far rather scarce Baltic material, for instance:

1448 Gelÿnde, Peter. Prussian anthroponym Galindo (Matusevičiūte 1939: 12). It was recorded in the Code of Elbing (Ger. Zinsbuch des Hauses Elbing (Preusss. Zins)), which listed Prussian land-tax payers. Such finds may be numerous. It is not clear whether there is a personal name Galind-. Perhaps we should consider the problem of the transition from Prussian $e$ to $a$ (gel-gal)? According to Kalwaitis (1910: 3, 5), Lithuanian names Galindas, Galinda are definitely related with historical memory, though the folklorist recorded other personal names from the spoken language. No examples of such transition have so far been found among Prussian proper names.

The article will finish with the discussion on another coin, which drove the scholars of Baltic proper names into serious 
considerations. In 2019, Xaverio Ballester announced the discovery of a $7^{\text {th }}$ century coin with the name Eivina[s] (57-58) carved in it, which may possibly be Prussian.

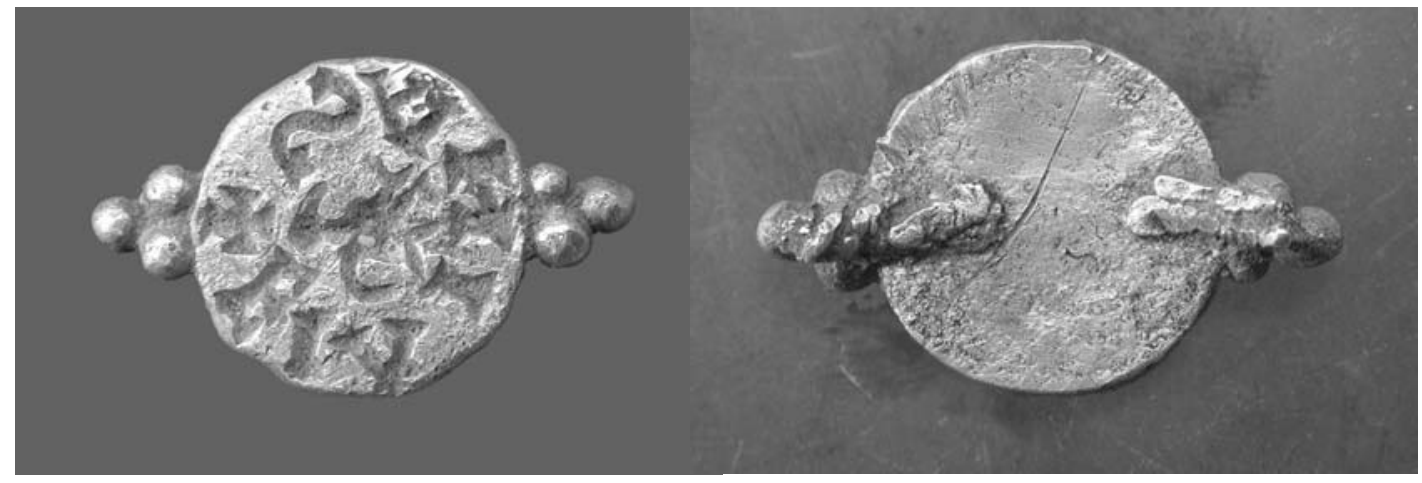

Photo by Lluís Molina Balaguer, Laboratory of Archeology, University of Valencia (see Ballester 2019: 58-59).

The author supports the idea that though the Galindians are considered Prussians, they also had certain differences, and the Galindian migration is not only a matter of debate but also a fact. Thus, this personal name could also refer to a Galindian, but it is only an assumption, like the presumably Baltic inscription on the coin. The role of the Visigoths should not be forgotten either. To explain its origin, we should look for parallels in the Baltic languages. The first stem $e i$ - is commonly found in the personal names of the Baltic languages, cf. Pr. personal name 1333 Eykant (OF 107 183r) Pr. 1386 Eikynt, Ibidem Eykynt in East Sambia (OF 107 61v-62r), 1396 mūsu ištikimajam Eykint in East Sambia (OF 107 53v-54r); 1333 Eykant (OF 107 183r), Pr. *Ei-kant- in West Sambia, 1387 Eyman, Eymon (OF 107 52v-53r), Pr. *Ei-man- , c. 1400 Eymante, Eymanthe (OF 161 145r), Pr. *Ei-mant- in Olsztyn voivodeship (also see Trautmann 1925: 136), cf. Lith. personal name Eĩ-butas, Ei-tautis, Ei-gáila, Ẽ̃-kintas (Salys 1933: 72; also see LPDB), where the root $e i$ - is linked with Lith. $e \tilde{l}-t i$ 'to go'. Also cf. Pr. personal name from Sambia 1387 Dese wege wil furen Eywon Spandenne (Spamdeme) vnd Swalgene von Waldow (Eywon Spandenne and Swalgene from Waldau want to lead this road) (SRP II 664), 1387 am montag... lis Maldenne Eywan dese nochgeschrebin wege furen. (on Monday... Maldenne Eywan was told to lead this road.) (SRP II 665). ${ }^{15} 1400$ Ibidem Eywan (having

${ }^{15}$ The manuscript legacy of the Order contains Litauische Wegeberichte (The Lithuanian Route Report) compiled in 1384-1402 (SRP II 663, 662701). The documents were prepared for publishing by Theodor Hirsch who 
possessions in Tromiten $^{16}$, Waldau $^{17}$ commandery) (OF 107 91r), may be Pr. ${ }^{*} E i$-vin-, as the recordings of proper names in the source are not very reliable, especially concerning the correct spelling of the second stem, see: c. 1400 the personal name Girbin was recorded twice and once as Girwin (OF 161 146r, 146v) in Olsztyn voivodeship. The shift of $b$ into $w$ in the middle of the word is a known phenomenon in Prussian proper names; most likely, Low German scribes pronounced $w$ instead of $b$. It may be Pr. *Gir-vin(also see Trautmann 1925: 33, 156), but also compare c. 1400 Pr. Gandewine or Gaudewine (OF 161 198r; Trautmann 1925: 29) in Olsztyn voivodeship, Pr. ${ }^{*}$ Gaud-vin-, also see the name Notangas. 1295 Gauwina, perhaps it could be Pr. *Gau-vina- (?) (SRP I 160 in Duisburg's Chronicle), it could be Pr. *Gau-vin- (?) (see Būga 1911 [1958]: 253-254); also Lewy 1913: 48; Trautmann 1925: 138). The root vin- is also used as the second component of Lith. personal names, compare Lith. 1412 Lengwyn, which corresponds to Samogitian Lengvinas, Bui-vin(a)s (Būga 1911 [1958]: 253), Do-vinas, Eit-vinas, Buĩ-vinas (Salys 1933: 121), also see Lith. Tarvinas. We

numbered 100 war routes and named them. Due to the material of great value to Lithuanian history, geography and ethnography, the documents were translated and published in Lithuanian in 1983 and 1988. Compare Lietuvos keliu aprašymai, padaryti kryžiuočiu žvalgu XIV amžiuje; its second edition was prepared by Juozas Jurginis and Algirdas Šidlauskas and translated by Jurginis. It was essential to include the original text. When Lithuanianising place names, their original spelling should have been provided. The spelling of proper names in the target language is a certain reconstruction of an authentic form, which tends to arouse doubt rather than agreement. Unidentified proper names are given in italics by forgetting that in the case of personal names, it was not only possible but also necessary to look through the collection of Prussian personal names published by Reinhold Trautmann as far back as 1925 . It would have been of help in identifying them. Works, chronicles and minor documents related to the history of Lithuania and other Baltic lands and languages written in Latin, Middle German, Middle High German, Middle Low German were translated into Lithuanian. Primary sources were not known in every case, there were transcripts, (un)available information about the authors of source texts. It would be necessary to prepare a critical edition of The Wegeberichte, because there is much more information and possibilities (we also have to bear in mind modern technologies). When translating the texts of the Order, cross-disciplinary cooperation should not be disregarded. See Blažienè 2017: 10-11.

${ }^{16}$ Pr. *Trum-it-, Ger. Tromitten in East Sambia.

${ }^{17}$ Pr. *Vald-av-, Ger. Waldau, now Nizovje in East Sambia. 
may think about old Lith. vin- with the vowel shift vain-: vainà 'cause, guilt' (Trautmann 1922: 156; Kuzavinis, Savukynas 1987: 342). It should not be forgotten that German personal names include the noun wini coming from Old High German wini 'friend' (FN 2005: 811). It is also clear that we should review German proper names. Since the author is already familiar with them, the diligent collection of personal names published by Ernst W. Förstemann in 1865 and the second expanded edition of 1900 were once again reviewed with great scrutiny. By the way, the books are still republished today. They have not lost their scientific value and relevance. Concerning VIN, Förstemann (1856: 1315) points out that the stem is traced to Old High German wini 'God' and is recorded in the personal names from the $5^{\text {th }}$ century, usually as the second component. The author provides 196 masculine personal names and 13 feminine personal names with -win. The coincidence of German and Prussian stems is sometimes astonishing, but it does not mean that these coincidences can be explained by the data of the Baltic languages, cf. Anglo-Saxon Dud-wine (Schönfeld 1911: 73), Ger. Raitwin (Förstemann 1856: 1316) and Pr. Raytwille (Trautmann 1925: 81, 149). It is doubtful that the aforementioned personal names are Baltic. Some scholars may come up with such a conclusion, but we need to take language contacts, Indo-European studies and extralinguistic factors into account and we cannot eliminate the chance of coincidences. The 1900 edition already spelled VINI. Old High German and Old Saxon wini 'friend' are found in personal names as early as the $5^{\text {th }}$ century; 226 masculine and 17 feminine personal names containing win- are already published (1900: 1608). There are coinciding roots, e.g. Ger. Dingewin (1900: 1610), cf. Pr. personal name Dynge (Trautmann 1925: 24, 135). Concerning ei, cf. Ger. Aido : Eido (1900: 45).

There are quite a few coincidences confirming that Eivina[s] may not be of Baltic origin, because the word-formation of the old personal names of different nations is in principle the same; they are usually two-stem personal names. This is a known fact from IndoEuropean studies; both components of two-stem personal names had a meaning, and only the old sources can answer the nationality question. It would indeed be important to find out how the name of a Prussian or a Galindian found a way to the coin of the $7^{\text {th }}$ century, bearing in mind that the first records of Prussian personal names date to the $13^{\text {th }}$ century only. However, that does not mean that they had been nameless until then. 
There is still much work to do to prove the origin of the personal name in question. The case of the Galindians, as well as that of Eivina[s], is not closed. The history of the Galindians and the spread of their name will be addressed by a number of future generations of Balticists, Germanists and Romanists. We can only hope that the sources will be more thoroughly read with the context in mind, and new data helping to confirm or reject the existing hypotheses will be found.

\section{References}

Ballester, X. 2019: El Chatón Visigótico De Eivina[s] Eivinas' Visigothic Bezel. Liburna 15 [Noviembre], 51-81.

Biolik, M. 1993: Namen der stehenden Gewässer im Zuflussgebiet des Pregel und im Einzugsbereich der Zuflüsse zur Ostsee zwischen Pregel und Memel (=Hydronymia Europaea 11). Stuttgart: Franz Steiner Verlag.

Blažienè, G. 2017: Vokiečių ordino raštų vertimo į lietuvių kalbą ypatumai. In: Vertimo studijos T. 10, 7-19.

Būga, K. 1911 [1958]: Apie lietuvių asmens vardus. In: Rinktiniai raštai I, 201-268.

CDP I - Codex Diplomaticus Prussicus. Urkunden-Sammlung zur älteren Geschichte Preußen aus dem Königl. Geheimen Archiv zu Königsberg nebst Regesten. Hrsg. von Johannes Voigt. Bd. I. Königsberg: Bei den Gebrüdern Bornträger, 1836.

CDP III - Codex Diplomaticus Prussicus. Urkunden-Sammlung zur älteren Geschichte Preußen aus dem Königl. Geheimen Archiv zu Königsberg nebst Regesten. Hrsg. von Johannes Voigt, Bd. III. Königsberg: Bei den Gebrüdern Bornträger, 1848.

Eckhel, A. J. 1797: Doctrina nvmorvm vetervm. Conscripta a iosepho eckhel. thesavro caesareo nvmorvm, gemmarvmqve vetervm, et rei antiqvariae in vniversitate vindobonensi docendae praefecto. Pars II, de moneta romanorvm. Volvmen VII. Continens nvmos imperatorios ab antonino pio vsque ad imperivm diocletiani. vindobonae: svmptibvs iosephi camesina et soc. inpressvm typis kvrtzbekianis.

Die littauischen Wegeberichte. In: Die Chronik Wigands von Marburg. Beilage I. In: Scriptores rerum prussicarus. Hrsg. Th. Hirsch. Bd. II. 1863, 664-711.

Dini, P. U. 2014: Foundations of Baltic languages. Vilnius: Vilnius University.

Dini, P. U. 2019: Baltu kalbu lyginamoji istorija. Vilnius: Mokslo ir enciklopediju leidybos centras.

Duisburg, P. of 1911: The Encyclopaedia Britannica: a dictionary of arts, sciences, literature and general information. Volume XXI, ed. by Chisholm, H. Cambridge, England: at the University Press, New York: 35 West $32^{\text {nd }}$ Street, 294. 
Dusburg, P. von 1861: Chronicon terrae Prussiae. Hrsg. von Max Toeppen. In: SRP I, 21-219.

Dusburgietis, P. 1985: Prūsijos žemès kronika. Parengè, ivadą ir paaiškinimus parašè, žemèlapi sudare R. Batūra. Vilnius: Vaga.

Jones, A. R. 2021: Ptolemy. Egyptian astronomer, mathematician, and geographer. Alternative Titles: Claudius Ptolemaeus, Ptolemy of Alexandria. https://www.britannica.com/biography/Ptolemy/Geographer

Fedčenko O. D. 2020: Baltskaja gidronimija central'noj Rossiji. In: Teoritičeskaja i prikladnaja lingvistika 6, 104-127.

Förstemann, E. W. 1856: Altdeutsches namenbuch. Erster Band. Personennamen. Nordhausen: Verlag von Ferdinand Förtstemann, Brüssel und Gent: bei Carl Muquardt, \& London: bei Williams \& Norgate.

Förstemann, E. W. 1900: Altdeutsches namenbuch. Erster Band: Personennamen. Zweite völlig umgearbeitete auflage. Bonn: P. Hanstein. [1966 republished in München: W. Fink].

Gamillscheg, E. 1934: Romania Germanica. Sprach- und Siedlungsgeschichte der Germanen auf dem Boden des alten Römerreiches, Bd. 1. Berlin-Leipzig: W. de Gruyter \& Co.

García Moreno, L. A. 2008: In: Prosopography, Nomenclature, and Royal Succession in the Visigothic Kingdom of Toledo. In: Journal of Late Antiquity 1(1), 142-156.

Goldbeck, J. F. 1785: Vollständige Topographie des Königreiches Preußen. Bd. 1. Königsberg-Leipzig: Kanter.

GZB - Thielen, P. G. 1958: Das grosse Zinsbuch des deutschen Ritterordens (1414-1438). Marburg: N. G. Elwert.

Hydronymia Europaea [1985, 1986]: Einführung, Ziele, Grundlagen, Methoden (Zeszyt wstępny, Cel, Metoda, Zasady redakcyjne) von Wolfgang P. Schmid, Kazimierz Rymut, Jürgen Udolph. Stuttgart: Franz Steiner Verlag Wiesbaden GMBH.

HAPr V - Historisch-geographischer Atlas des Preußenlandes. Lfg. 5. Hrsg. von Hans Mortensen, Gertrud Mortensen, Reinhard Wenskus, Helmut Jäger. Wiesbaden: Franz Steiner Verlag, 1978.

Hartmann, E. 1958: Der Kreis Osterode (Ostpr.). Daten zur Geschichte seiner Ortschaften. In: Ostdeutsche Beiträge aus dem Göttinger Arbeitskreis Band X. Würzburg: Holzner-Verlag.

Jovaiša, E. 2014: Aisčiai. Raida. Vilnius: Lietuvos edukologijos universitetas, Lietuvos mokslu akademija.

Jovaiša, E. 2020: The Aestii. The Western Balts. Kaunas: Vytautas Magnus University.

Kalwaitis, V. 1910: Lietuwiszku Wardu Klètelè. Tilžė: Spausdinta Otto v. Mauderodès.

Karaliūnas, S. 2015: Baltu etnonimai. Vilnius: Lietuvių kalbos institutas.

Kasiske, K. 1934: Die Siedlungstätigkeit des Deutschen Ordens im östlichen Preußen bis zum Jahre 1410. Einzelschriften der Histo- 
rischen Kommission für ost- und westpreußische Landesforschung. Bd. 5. Königsberg i. Pr.: Kommissionsverlag Gräfe und Unzer.

Leyding-Mielecki, G. 1947: Słownik nazw miejscowych okregu mazurskiego. Cz. I. Olsztyn: Państwowe wydawnictwo Naukowe.

Lewy, E. 1904. Die altpreussischen Personennamen. Breslau: Buchdruckerei H. Fleischmann.

Lietuvos kelių aprašymai, padaryti kryžiuoti žvalgu XIV amžiuje. In: Kraštas ir žmonès. Lietuvos geografiniai ir etnografiniai aprašymai (XIV-XIX a). Antras papildytas leidimas. Parengė J. Jurginis, A. Šidlauskas. 1988. Vilnius: Mokslas, 8-42.

LKŽe - Lietuvių kalbos žodynas 1-20, 1941-2002, elektroninis variantas, redaktorių kolegija: Gertrūda Naktinienè (vyr. red.), Jonas Paulauskas, Ritute Petrokienė, Vytautas Vitkauskas, Jolanta Zabarskaitè. Vilnius: Lietuvių kalbos institutas, 2005 (updated version, 2008). Internet access: www.lkz.lt

LPDB - Lietuviu pavardžiu duomenu bazé. Internet access: http://lkiis.lki.lt

Luchtanas A., Poliakovas O. 2018: Galinda Europos platybėse: Archeologija, istorija, lingvistika. In: Lietuvos istorijos studijos 41, 9-39.

Matusevičiūtè, I. 1939: Kiek naujos medžiagos prūsų vardynui. In: Archivum Lithuanicum 8, 10-18.

MHW - Monumenta Historiae Warmiensis oder Quellensammlung zur Gechichte Ermlands. Herausgegeben von dem historischen Vereine für Ermland. Bd. I. I Abtheilung. Codex Diplomaticus Warmiensis. Oder Quellensammmlung zur Geschichte Ermlands. 1860. Mainz: Verlag von Hans Kirchheim. Codex Diplomaticus Warmiensis oder Regesten und Urkunden zur Geschichte Ermlands. Gesammmelt und im Namen des historischen Vereins herausgegeben von Carl Peter Woelky un Peter Saage. Urkunden der Jahre 1231-1340. Bd. I. Mainz: Verlag von Hans Kirchheim, 1860

Moll, F. de B. 1982: Els llinatges Catalans (Catalunya. País Valencià. Illes Baleares. Mallorca: Moll.

Muratori, L. A. 1900: Rerum italicarum scriptores. Raccolta degli storici italiani dal cinquecento al millecinquecento. Nuova edizione riveduta, ampliata e corretta con la direzione di G. Carducci e V. Fiorini. T. 26. Città di Castello: coi tipi della casa editrice S. Lapi.

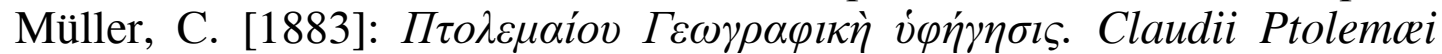
Geographia. E codicibus recognovit, prolegomenis, annotatione, indicibus, tabulis instruxit Carolus Müllerus. Voluminis primi, pars prima. Parisiis: editore Alfredo Firmin Didot, Instituti Francici typographo, Via Jacob, 56.

NMP II - Nazwy miejscowe Polski, t. II C-D (pod redakcją Kazimierza Rymuta), 1997, Kraków: Instytut Języka Polskiego (Polska Akademia Nauk). 
NMP III - Nazwy miejscowe Polski, t. III E-I (pod redakcją Kazimierza Rymuta), 1999, Kraków: Instytut Języka Polskiego (Polska Akademia Nauk).

Nowakowski, W. 1995: Od Galindai do Galindite. Z badań nad pradziejami baltyjskiego ludu z Pojezierza Mazurskiego. Barbaricum, t. 4. 105 s.+ XXI tabl.

Nowakowski, W. 1996: Galinder. Archäologisches. Reallexikon der Germanischen Altertumskunde, Bd. 10, Lfrg. 3/4, hrsg. von Heinrich Beck, Bonn - Heiko Steuer, Freiburg, Dieter Timpe, Würzburg, 329-330.

OF - The German Order Folios from the Secret State Archive of Prussian Cultural Heritage in Berlin.

Piel, J. M. 1936: Os nomes germânicos na toponimia portuguesa. 1. Lisboa: Imp. Nacional.

Piel, J., Kremer, D. 1976: Hispano-gotisches Namenbuch. Der Niederschlag des Westgotischen in den alten und heutigen Personen- und Ortsnamen der Iberischen Halbinsel. Heidelberg: Carl Winter Universtätssverlag.

PSRL II - Polnoe sobranie russkih letopisey, izdannoe po vysotshayshemu poveleniyu arheografitsheskoyu komissiyeyu. Tom vtoroy. III Ypatievskaya letopis. Sanktpeterburg: V tipografii Eduarda Pratsa, 1845.

Przybytek, R. 1993: Ortsnamen baltischer Herkunft im südlichen Teil Ostpreußens (=Hydronymia Europaea, Sonderband). Stuttgart: Franz Steiner Verlag.

PUB III - Preußisches Urkundenbuch, Bd. 1. Lfg. 1 (1335-1342). Herausgegeben im Auftrage der Historischen Kommission für ostund westpreussische Landesforschung. Hrsg. von Dr. Hans Koeppen. Marburg: N. G. Elwert Verlag, 1958.

PUB III - Preußisches Urkundenbuch, Bd. 3. Lfg. 2 (1342-1345). Herausgegeben im Auftrage der Historischen Kommission für ostund westpreussische Landesforschung. Hrsg. von Dr. Hans Koeppen. Marburg: N. G. Elwert Verlag, 1958

PUB IV - Preußisches Urkundenbuch, Bd. 4 (1346-1351). Heraus-gegeben im Auftrage der Historischen Kommission für ost- und westpreussische Landesforschung. Hrsg. von Dr. Hans Koeppen. Marburg: N. G. Elwert Verlag, 1960.

Radvanas, J. after 1592: Radivilias. Sive, de vita, et rebvs præclarissime gestis, immortalis memoriæ, illvstrissimi principis Nicolai Radivili Georgii Filii, DV. Cis in Dubinki ac Bierze, Palarini Vilnenfis, \&c. ac Exercitruum Magni Ducatus Lituaniæ, Imperatoris Fortiflimi. \&c. LIBRI QVATVOR. IOANNIS RADVANI LIT: Iuffu \& Auctoritate Mag.D.Ioannis Abramovicz, in Worniany, Præfidis Derpatenfis, Capita - I Lidenfis Vendelis. Addite est Oratio Funebris, Generofi D. Andrea Voloni, Secretarij Sacre Regia Mageftaris, \& 
quorumdam Auctorum Epigrammaia. VILNAE METROPOLI LITVANORVM: Ex Officina Ioannis Kartzani.

Radvanas, J. 1997: Radviliada (reng. Sigitas Narbutas). Vilnius: Vaga.

Sachs, G. 1932: Die germanischen Ortsnamen in Spanien und Portugal. In: Berliner Beiträge zur Romanischen Philologie, II, 4. Jena-Leipzig: W. Gronau.

Salys, A. 1933: Mūsų lietuviškieji vardai. In: Gimtoji kalba, 69-74, 121-122.

Schmid, W. P. 1996: Galinder. Etymologisches. Reallexikon der Germanischen Altertumskunde, Bd. 10, Lfrg. 3/4, hrsg. von Heinrich Beck, Bonn, Heiko Steuer, Freiburg, Dieter Timpe, Würzburg, 325-327.

Schroetter, F. von 1802-1810. Karte von Ostpreussen nebst PreussischLitauen und Westpreussen nebst des Netzedistricts, Maßtab 1:150000 (gezeichnet um 1790), Berlin: Simon Schropp.

SGKP - Stownik geograficzny Królewstawa polskiego i innych krajów slowianskich. Tom 2. Wydavi pod redakcija Bronisława Chlebinskiego i Władisława Walenskiego, Warszawa: Nakładem Władisława Walenskiego. 1884.

SRP - Scriptores Rerum Prussicarum. Die Geschichtsquellen der preussischen Vorzeit bis zum Untergange der Ordensherrschaft. Herausgegeben von Theodor Hirsch, Dr. Max Töppen, Dr. Ernst Strehlke. Bd. 1. Leipzig: Verlag von S. Hirsel, 1861.

SUB - Urkundenbuch des Bisthums Samland, hrsg. von C. P. Woelky und H. Mendthal. Leipzig: Duncker \& Humblot, 1891.

Šafařik, P. J. 1837: Slovanské starožitnosti. Oddíl Děgepisný. Pomocj Českého Museum. W Praze: Tiskem Jana Spurného.

Schönfeld, M. 1911: Wörterbuch der altgermanischen Personen- und Völkernamen. Nach der Überlieferung des klassischen Altertums, bearbeitet von M. Schönfeld. Heidelberg: Carl Winter's Universitätsverlag.

Skardžius, P. 1943/1996: Lietuviu kalbos žodžiu daryba. Fotografuotinis leidimas. Rinktiniai raštai 1. Vilnius: Mokslo ir enciklopediju leidykla.

Tacitus. 2006, 2013: Tacitus on Germany. Translator Thomas Gordon. EBook. Access: http://www.gutenberg.org/files/2995/2995-h/2995h.htm The Project Gutenberg Ebook Of Tacitus on Germany, by Tacitus.

Toeppen, M. 1870: Geschichte Masurens. Ein Beitrag zur preussischen Landes- und Kulturgeschichte. Danzig: Verlag von Theodor Bertling.

Töppen, M. 1853: Geschichte der Preussischen Historiographie von Peter v. Dusburg bis auf K. Schütz oder Nachweisung und Kritik der gedruckten und ungedrucken Chroniken zur Geschichte Preussens unter der Herrschaft des deutschen Ordens. Berlin: Verlag von Wilhelm Hertz (Besser'sche Buchhandlung). Druck von Friedrich Fromann in Jena, 1-15.

Toporov, V. N. 1979: Prusskij jazyk. Slovar'. E-H, Moskva: Nauka. 


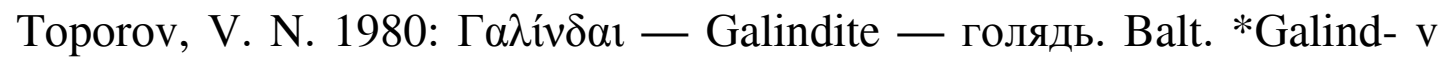
etnolingvističeskoj i areal'noj perspektive. In: Etnolingvističeskije $i$ lingvisticeskite aspekty etničeskoj istoriji baltskich narodov. Riga: Zinātne, 124-136.

Toporov, V. N. 1980: Baltijskij element k severu ot Karpat: Etnonimičeskaja osnova *Galind- kak znak baltijskoj periferiji. In: Slavica Occidentalis t. 29, 247-252.

Toporov, V. N. 1983: Galindy v zapadnoj Evrope. Balto-slavianskije issledovanija 1982, 129-132.

Trautmann, R. 1925: Die altpreußischen Personennamen. Göttingen: Vandenhoeck \& Ruprecht.

Vaillant, J. 1696: Numismata Imperatorum Romanorum Præstantiora A Julio Cæsare Ad Tyrannos Usque. Per Joannem Vaillant Bellovacum, Do\&t. Med. \& Seren. Ducis Cenomanenfium Antiquarium. * Tomus secundus. De Aureis Et Argenteis. Editio tertia plurimis rariflimis Regum \& Urbium nummis ut \& maximis \& quinariis auctior. Cui Accessere Eorum Omnium Interpretationes. Amstelodami, Apud Georgium Gallet.

Voigt, J. 1828: Geschichte Preußens von den ältesten Zeiten bis zum Untergange der Herrschaft des Deutschen Ordens. Bd. 3. Die Zeit vom Frieden 1249 bis zur Unterwerfung der Preussen 1283. Königsberg: im Verlage der Gebrüder Bornträger.

Wenskus, R., Timpe, D. 1996: Galinder. Historisches. Reallexikon der Germanischen Altertumskunde, Bd. 10, Lfrg. 3/4, hrsg. von Heinrich Beck, Bonn, Heiko Steuer, Freiburg, Dieter Timpe, Würzburg, 327-329.

Wunder, H. 1968: Siedlungs- und Bevölkerungsgeschichte der Komturei Christburg (13.-16. Jhdt.). Wiesbaden: Otto Harrassowitz. 